\title{
Black drawings at the cave site of Gua Pondoa, Southeast Sulawesi: The motifs and a comparison with pigment art elsewhere in Sulawesi and the broader Western Pacific region
}

\author{
Budianto Hakim, Sue 0'Connor and David Bulbeck
}

\begin{abstract}
Drawing on cave surfaces constitutes a human production that involved depicting objects, events or symbolic notions. With this perspective, we can gain an insight into both mundane and ritual aspects of the life of earlier communities. Here we look at the art of Gua Pondoa in the Matarombeo Massif of Southeast Sulawesi and discuss its commonalities with other pigment art in Sulawesi and that found elsewhere in the Western Pacific region referred to under the umbrella term the 'Austronesian Painting Tradition', and find both similarities and differences.
\end{abstract}

Keywords: Gua Pondoa, Matarombeo Massif, Southeast Sulawesi, cave drawings, Austronesian Painting Tradition

\section{Background}

Sulawesi has many regions of limestone karsts where numerous caves and rockshelters have formed along cliff margins as a result of long-term erosion. These caverns and overhangs provide natural protection from the elements and so have long attracted human habitation, notably during the Palaeolithic and Mesolithic, prior to the establishment of permanent village settlements. Of particular appeal were roomy caverns with an open floor area, providing adequate light and comfortable space for maintenance and subsistence activities and large enough for group dwelling (Hakim 2006). In Southwest Sulawesi, the oldest known habitation deposits date to at least 40,000 years ago, and the use of caverns for ceremonial purposes evidently has an equal time depth (Brumm et al. 2017). This is demonstrated by uranium-thorium (UTh) dates of between c. 40,000 and 18,000 years ago obtained on calcite deposits overlying hand stencils and naturalistic ungulate depictions painted on the walls of Maros limestone caverns (Aubert et al. 2014). Despite the lack of direct dating evidence, cave paintings are also likely to have been produced in Sulawesi during the early and middle Holocene (Oktaviana et al. 2016; Taçon et al., this volume). Then in the last several thousand years a distinctive rock art tradition 
arose, the so-called 'Austronesian Painting Tradition' (APT) (Ballard 1992), often in concert with the specialised use of caves for burial and ceremonial rites during the Neolithic and Metal Phase (Bulbeck, this volume).

Within Sulawesi, hand stencils are sometimes regarded as a marker of pre-APT art production, but they are also often found at the same sites as APT motifs. Oktaviana et al. (2016) found that the 52 documented rock art sites from South Sulawesi Province included 29 with hand stencils only, a 30th pre-APT site with a probable suid (dated to around 40,000 years ago), 18 sites with hand stencils and APT motifs, and a remainder of four entirely APT sites. In Southeast Sulawesi Province, hand stencils have been encountered only occasionally, specifically at the Gua Anawai site in the Matarombeo Massif (Oktaviana et al. 2016), and at three sites (all of them dominated by APT paintings) on Muna Island (Oktaviana, this volume). Gua Pondoa, one of the three Matarombeo Massif APT sites referred to by Oktaviana et al. (2016), is the focus of this contribution.

This paper describes the black charcoal drawings recorded by the first author on the rock surfaces of the inner chamber of the Gua Pondoa limestone cave. The subject and style of the motifs suggest that the drawings fit within the APT, as originally defined by Ballard $(1988,1992)$. The Gua Pondoa motifs are compared with other APT repertoires, with a focus on Sulawesi examples. The resulting comparisons are included in a consideration of the possible symbolic associations represented by the Gua Pondoa drawings and the implications for understanding prehistoric Malayo-Polynesian (Austronesian) lifeways in the vicinity of Gua Pondoa.

\section{The Austronesian Painting Tradition}

The APT is characterised by the positioning of some paintings in 'inaccessible but highly visible locations, most commonly sea cliffs' (Ballard 1992:98). Boats, anthropomorphs and 'sun symbols' are prominent and hand stencils are also often found associated with early APT art (Ballard 1988). It has been suggested that the placement of the paintings may have had significance in terms of visual signalling of rites/beliefs, and also that there may be a co-association of painted art with human burials, including boat/canoe burials (Ballard et al. 2004). For example, Röder (1938:88) notes that in the Arguni cliff sites in Papua, sun symbols similar to those found in the painted art were also painted on the prows of boats and boat-shaped coffins (see also Ballard 1992; Ballard et al. 2004). APT art is thought to postdate the movement of Austronesianspeaking communities into eastern Indonesia but to be possibly as late as $2000 \mathrm{BP}$ (Ballard 1992:98; Ballard et al. 2004:98), and may have been an innovation linking island communities in a shared symbolic tradition (O'Connor et al. 2015).

In terms of colour, the earliest examples of the APT are red pigment; however, areas where black art dominates are known. For instance, in Vanuatu, and to a lesser extent in New Caledonia and Fiji, a painted assemblage is produced that observes many of the same conventions in terms of the placement of art (despite a shift from cliff to cave sites in some locations), but a much higher proportion of the art is black pigment. Detailed studies in a few regions have shown that the APT style develops and changes over time, whilst retaining some of its characteristic motifs (Wilson 2002:225). Although in the APT red pigment art is usually thought to be older than black pigment art, this is not always the case; on the basis of superimposition of motifs, the earliest phase of Vanuatu's art sequence has both black and red paintings and stencils, similar to painted art assemblages in New Ireland and New Caledonia. The latter's painted art is almost exclusively black, and includes stencils and linear motifs, while the painted motifs include leaf shapes, anthropomorphs and symmetrical linear geometric forms (Wilson 2002). 


\section{Gua Pondoa in the context of the geography and geology of North Konawe District}

Gua Pondoa falls within Desa (Village) Pondoa, Kecamatan (Subdistrict) Wiwirano, Kabupaten (District) Konawe Utara, Southeast Sulawesi Province. The administrative centre of North Konawe is Asera, which lies about $174 \mathrm{~km}$ from Kendari, the capital of Southeast Sulawesi. Geographically, Konawe Utara lies slightly to the south of the equator, between $03^{\circ} 00^{\prime}$ and $04^{\circ} 15^{\prime} \mathrm{S}$, and extends $121^{\circ} 44^{\prime}$ to $123^{\circ} 9^{\prime} \mathrm{E}$ west to east. Land surface area is around 510,000 hectares (BPK RI 2009).

The physical environment of North Konawe consists of lowlands and highlands, including coastal beach at the east, rivers and extensive swamp, and mountains to the west. Tropical forest is found everywhere. The hinterland can be accessed from the swamps and lowlands by river courses, which were the major traffic routes before land was cleared for roads (Budianto Hakim, pers. observations).

In terms of lithology (Nurhasan et al. 2013), North Konawe consists of ophiolites at its east near Lasolo Gulf, stretching to the west and widening to the north at the Tangeboruwaki range. These ophiolites include periodite, harzburgite, dunite, gabbro and serpentinite minerals. In various places, the ophiolitic rocks are interspersed with alluvial sediments such as river pebbles and gravels, sand and clay. There are also non-ophiolitic rocks, notably calcilutite with shale and chert intercalations, extending along the middle of North Konawe from Matanakasi Mountain to Wiwirano at the west, producing the Matarombeo Massif. These rocks are part of the Matano Formation. In certain places, such as the Samandete and Tetewatu locales, the calcilutite is interspersed with alluvial sediments (river pebbles and gravels, sand and clay).

The Matarombeo Massif is characterised by karstic towers. The streams lacing the karsts join up along the Solo Lawe River, which flows east to debouch at the Lasolo Gulf. At the karst bases there are many caves, rockshelters and tunnels such as the Rukuo tunnel produced by underground streams (Intan 2005).

\section{Gua Pondoa site description}

The geographic coordinates of Gua Pondoa are $3^{\circ} 24^{\prime} 20^{\prime \prime S} 122^{\circ} 3^{\prime} 28^{\prime \prime} \mathrm{E}$, and it lies 247 metres above sea level ( $\mathrm{m}$ asl). The cave is an underground cavern with two entrances inside a limestone hill. The interior of the cave is damp with wall drips in some places that foster the growth of fungi and lichen. It includes a connecting passageway between the front chamber, which is partially lit, and the larger rear chamber, which is poorly lit and houses a bat colony. Human habitation at the site appears to have been desultory at best based on the scarcity of subsistence refuse (animal bones and shell fragments) or artefacts (some earthenware fragments but no lithics) recorded on the cave surface. However, various human remains including a skull, mixed with earthenware pottery fragments, were observed in the front chamber, demonstrating that the site was used for mortuary disposal. The rear chamber, which measures approximately $15 \mathrm{~m} \times 15 \mathrm{~m}$ in area and $5 \mathrm{~m}$ in height, contains the art gallery.

Both the walls and the ceiling of the rear chamber contain artwork. All the recorded art on the walls has been drawn on an old flowstone surface, which provides an even and regular 'canvas' compared with the uneven limestone surface that the flowstone covers. The majority of the artwork is concentrated together in what may be considered the 'main panel'. Within that panel, some drawings appear to cluster in groups, which allows for the possibility that the groups each 
represent a single story or message envisioned by the artist(s). All of the paintings were created using charcoal and the forms that can be recognised include boats, people including some in elaborate headdress, animals, sun symbols and a variety of geometric forms (Figure 7.1).

\section{Gua Pondoa: Interpretation of the motifs}

Four definite, and probably more, examples of boats can be recognised. Two are located towards the top of the main panel (Figure 7.1), well above head height. Although in highly schematised form, one of them (Figure 7.2) appears to include a sail-although based on its size and positioning, this may be a ceremonial standard or banner, rather than a sail. Inside the boat are five upright human figures. The figures at the ends of the boat may be navigators. Interestingly, this boat has neither upswept prow or stern or a steering oar as is common in boat depictions elsewhere in Indonesia (O'Connor 2003; Lape et al. 2007; Marschall and Wäfler 2012). The second boat (Figure 7.3) looks like a long boat with a line of standing passengers from the stern to near the bow, where another figure separated from the passengers may be the boatman who is navigating the boat. The curvilinear designs above the passengers' heads may be symbolically related to the boat design or signify the movement of the craft. A third craft is depicted at centre far right of the main panel. This motif group shows two highly abstracted human figures with elaborate headdresses standing on what may be either the prow or stern of a boat. A fourth craft, to the left central area of the panel appears to have one human central figure, a possible steering oar and an upright decorative 'standard' like that seen on the first craft. Other horizontal lines with human figures shown standing on or just above them also likely represent watercraft in highly schematised form. An example can be seen close to the base of the main panel to the left of an internally speckled 'sun symbol' (Figure 7.1).

Stick figure human depictions, with the arms and legs splayed, are common (Figure 7.1). Some of them lack digits or headdresses/adornments (Figure 7.2), while others distinctly show the head with one or two headdresses (Figures 7.4 and 7.5). Two similarly depicted humans with arms outstretched and touching, as in Figures 7.2 and 7.5, appear to be deliberately juxtaposed, suggesting some connection between them. The highly schematised nature of many of the figurative motifs, and incorporation of curvilinear and linear motifs into figurative motifs, makes it difficult in some cases to determine whether anthropomorphic or geometric motifs are represented (Figure 7.6).

There are some readily recognisable depictions of mammals shown with four limbs, head, body and tail. The four clearest examples, towards the upper right of the main panel, are shown enlarged in Figure 7.3, including the two lower zoomorphs, which (from left to right) might represent a horned water buffalo and a dog facing each other. If the water buffalo interpretation is correct, this could be either the wild endemic Anoa or the introduced, domestic form (Bubalus bubalis). Other possible candidates for the horned quadruped are a goat or deer. All of the five mammals referred to here have been documented in the prehistoric faunal record for South Sulawesi (Simons 1997; Simons and Bulbeck 2004), and so would probably have been familiar to the Gua Pondoa inhabitants either as domesticates or forest game at the presumed time of production of APT art in Sulawesi. 


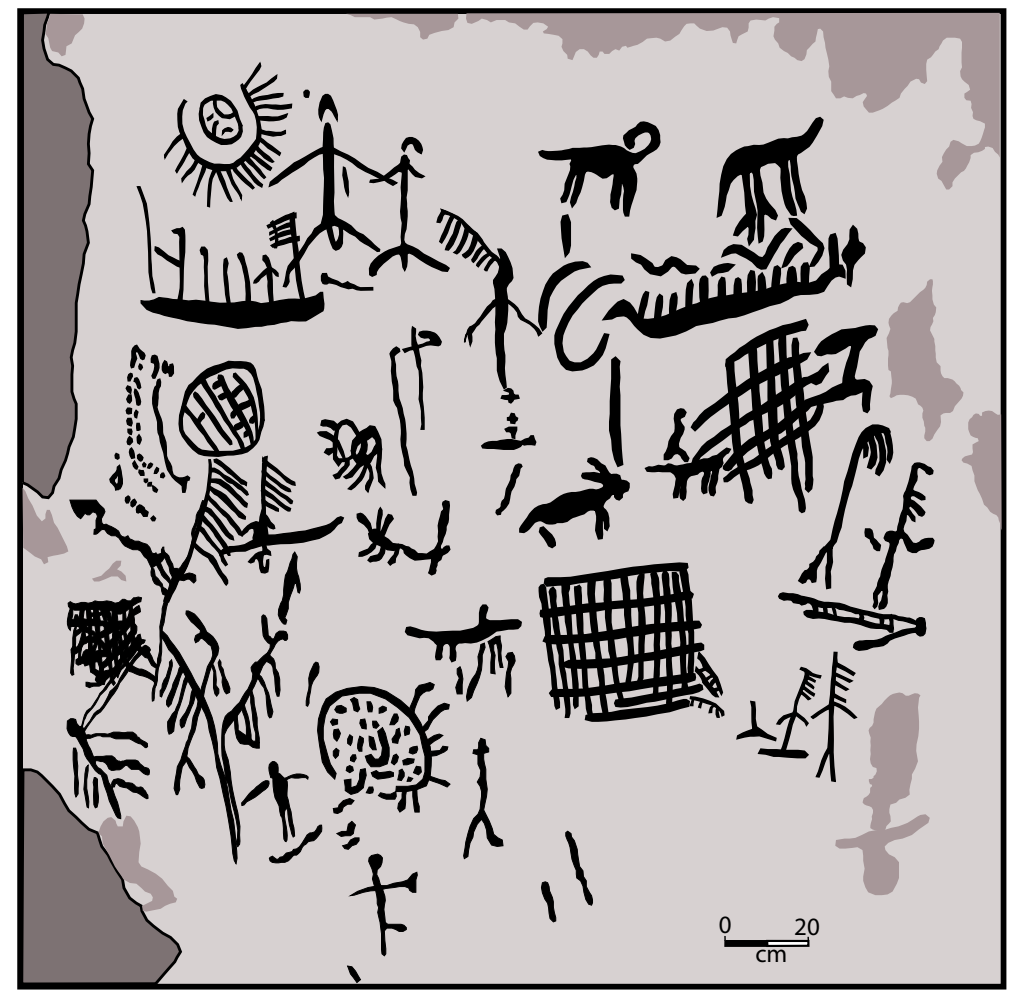

Key:

$\square$

Back cave wall

Limestone rock surface

$\square$

Old flowstone

Charcoal drawings

Figure 7.1: Gua Pondoa main panel.

Source: Drawing by David Bulbeck from photograph by Budianto Hakim.

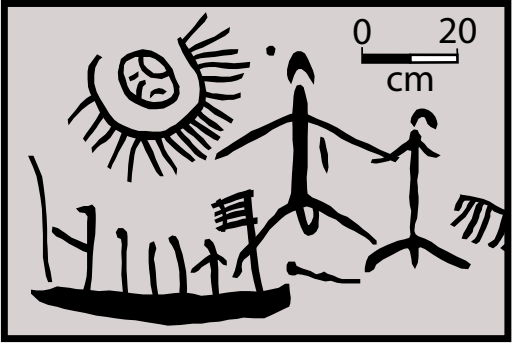

Key:

Old flowstone Charcoal drawing

Figure 7.2: Motifs of boat with passengers (lower left), sun symbol (upper left) and two anthropomorphs (right).

Source: Drawing by David Bulbeck from photograph by Budianto Hakim.

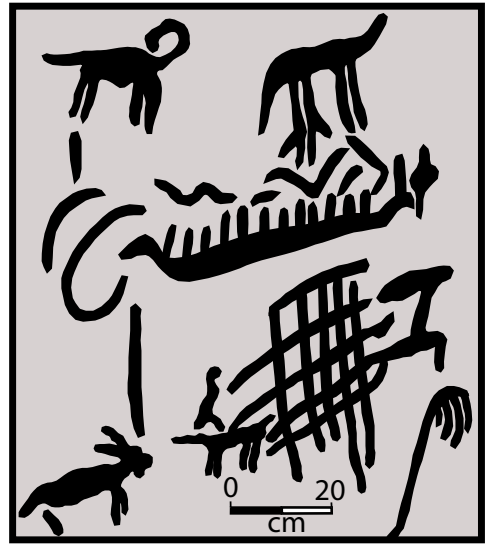

Key:

Old flowstone Charcoal drawing

Figure 7.3: Motifs of boat with schematised human figures (upper centre), quadrupeds (top and bottom centre) and geometric grid pattern (lower centre).

Source: Drawing by David Bulbeck from photograph by Budianto Hakim. 


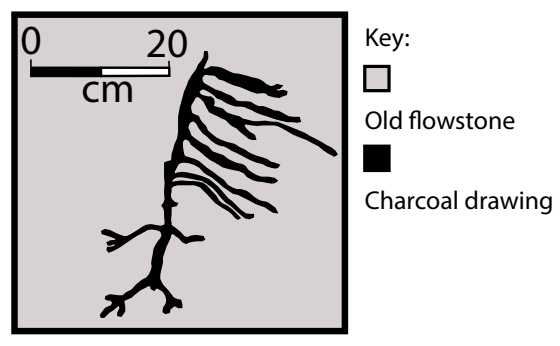

Figure 7.4: Motif of anthropomorph with frond-like headdress.

Source: Drawing by David Bulbeck from photograph by Budianto Hakim.

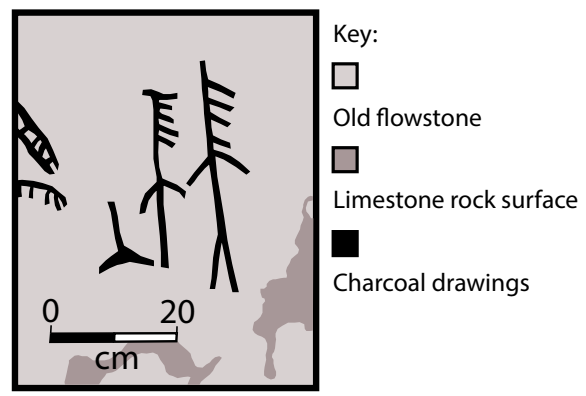

Figure 7.5: Two anthropomorphs with headdresses. Source: Drawing by David Bulbeck from photograph by Budianto Hakim.

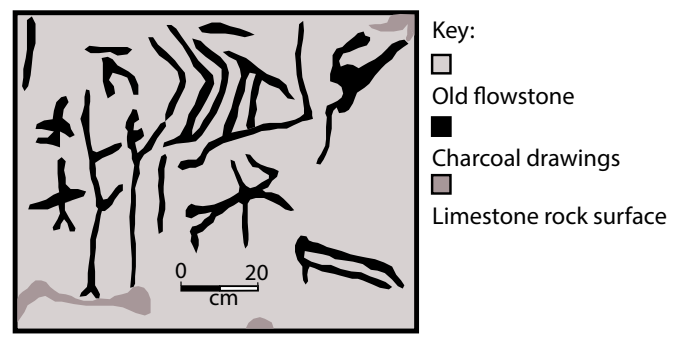

Figure 7.6: Possible anthropomorphs associated with geometric motifs.

Source: Drawing by David Bulbeck from photograph by Budianto Hakim.

Curvilinear and linear geometric motifs are also abundant in Gua Pondoa (Figures 7.7 to 7.10). While it is not possible to interpret these motifs, the fact that the headdresses on the anthropomorphs and the uprights on the boats are similar might suggest that they represent ritual or ceremonial regalia, such as feather or palm frond head or body decorations (e.g. Figures 7.4 and 7.5). In addition, towards the bottom left of the main panel are two intersecting lines with shorter lines sprouting at right angles, in what may be an abstract representation of palm fronds (Figure 7.9). Palm fronds are still used in Indonesia during ceremonial occasions as free-standing uprights or standards, much as they are in many religions around the world. The motif in Figure 7.9 is reminiscent of these decorations used during ceremony.

Two definite sun symbols have been identified, based on their exterior rays or spokes radiating out from a circular form at the centre (see definition in O'Connor 2003). One is located at the top left of the main panel (see Figure 7.2 for detail) and the second is positioned beneath the main panel (Figure 7.11). A third possible sun symbol appears central left near the base of the main panel; however, the radiating spokes are irregularly represented (Figure 7.1).

Geometric designs along with depictions of humans and boats, are the dominant motifs at Gua Pondoa. Spread widely across the main panel, geometrics include crescents, circles infilled with lines or dots, checkerboard grates, lattices, linear frond-like motifs and dotted and continuous lines (Figure 7.1). Similar forms are also present beneath the main panel (see Figures 7.6 and 7.10), and include a design with rhomboids drawn along a central line (Figure 7.12). Some of them may be based on decorative craftwork, hand-held implements or natural phenomena, but any specific interpretation would be speculative.

In summary, the Gua Pondoa drawings constitute a diverse body of art, including passengers in boats, other anthropomorphs wearing elaborate head decorations, quadruped animals including possible dogs and water buffalo, sun symbols, and a variety of linear and curvilinear designs. There are many instances of designs touching or overlapping with each other (Figure 7.1), but the nature of any intended associations is unclear. As explored in more detail below, the Gua Pondoa repertoire includes signature APT motifs (Ballard 1988). 


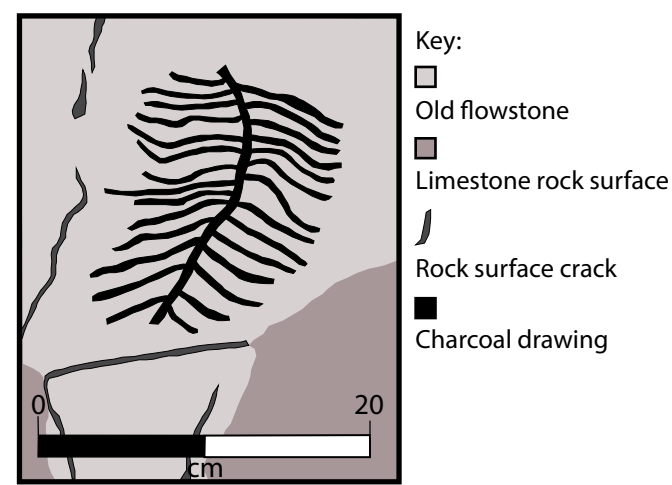

Figure 7.7: Linear frond-shaped motif.

Source: Drawing by David Bulbeck from photograph by Budianto Hakim.

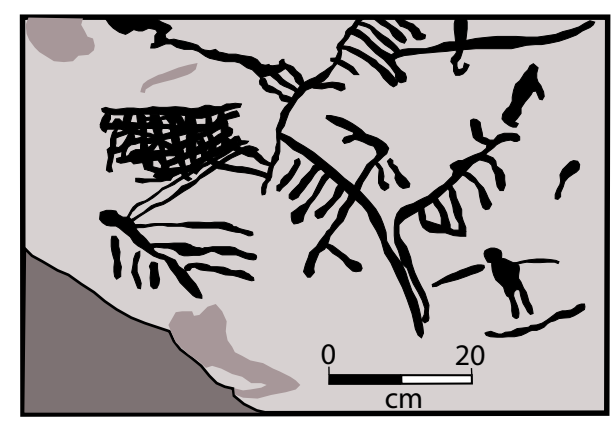

Key:

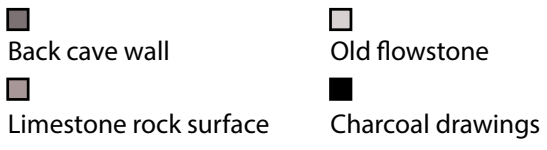

Figure 7.9: Linear motifs (left and centre), cross-hatched motif (left) and anthropomorph on schematised boat (right).

Source: Drawing by David Bulbeck from photograph by Budianto Hakim.
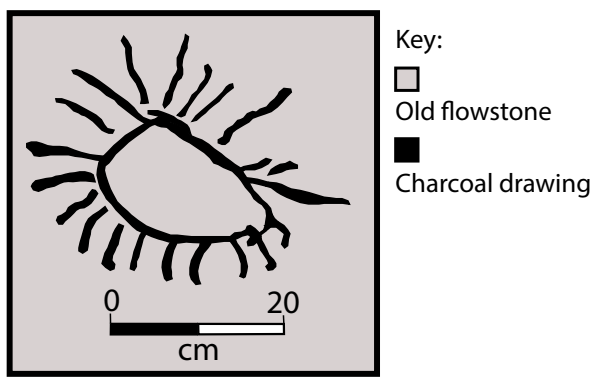

Figure 7.11: 'Sun symbol' motif positioned beneath the main panel.

Source: Drawing by David Bulbeck from photograph by Budianto Hakim.

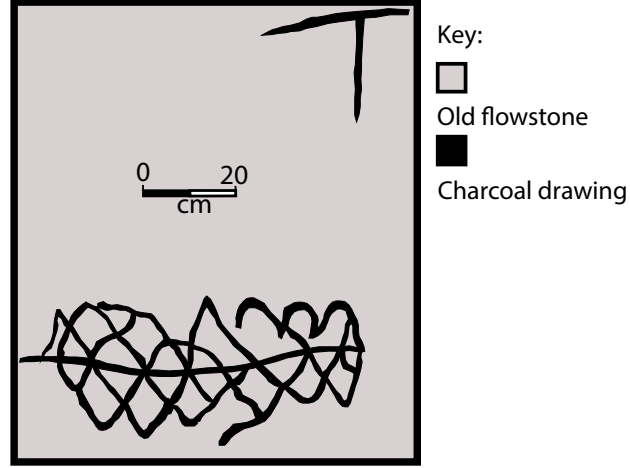

Figure 7.8: Curvilinear geometric motif.

Source: Drawing by David Bulbeck from photograph by Budianto Hakim.

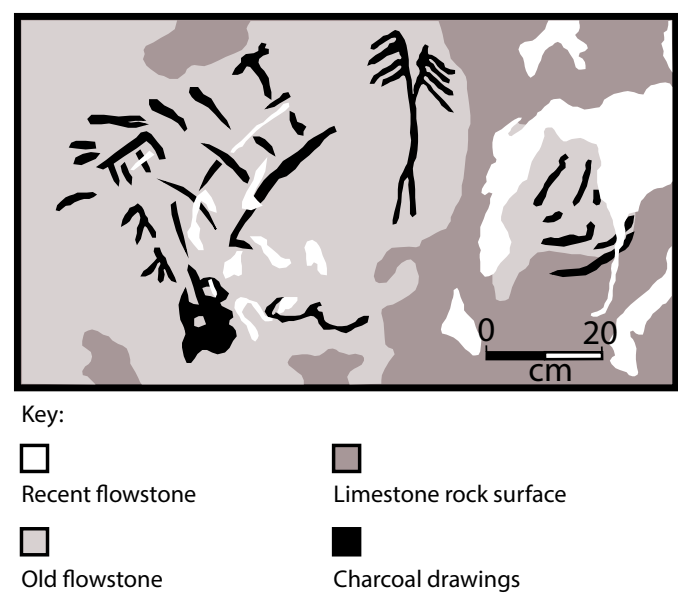

Figure 7.10: Indeterminate geometric motifs (left), stylised anthropomorph with headdress (centre) and abstract curvilinear motifs (right).

Source: Drawing by David Bulbeck from photograph by Budianto Hakim.

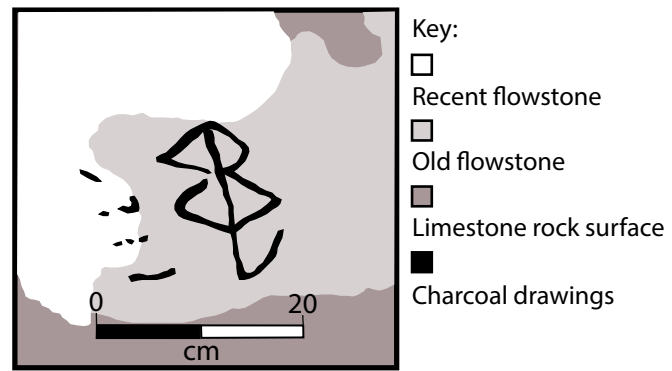

Figure 7.12: Curvilinear kite-shaped motif. Source: Drawing by David Bulbeck from photograph by Budianto Hakim. 


\section{Sulawesi comparisons}

The geographically closest sites of relevance may be the caverns of the Towuti-Routa region, approximately $25 \mathrm{~km}$ to the west of Gua Pondoa. The comparison lies not in the rock art, which consists almost entirely of hand stencils at Towuti-Routa (Oktaviana et al. 2016), but in the mortuary assemblages (Bulbeck et al. 2016). Curvilinear designs shared between the decorated mortuary pottery at Gua Talimbue (1st millennium AD) and Gua Pondoa include semi-circles arranged in compositions, frond designs, compositions of dots in lines or fields, and lattices of lines. The Gua Pondoa boat designs evoke the boat-shaped coffins placed in various TowutiRouta caverns. Although in the Towuti-Routa case the coffins' time range was evidently restricted to the second half of the 2 nd millennium $\mathrm{AD}$, coffin interment has greater antiquity in Indonesia probably stretching back into the Neolithic or beyond (Ballard et al. 2004).

The largest body of rock art in Southeast Sulawesi is found in the karsts of Muna Island, approximately $220 \mathrm{~km}$ to the south of Gua Pondoa. As described by Kosasih (1983) and Oktaviana (this volume), and extensively illustrated by Marschall and Wäfler (2012), the Muna Island rock art sites have a preponderance of human figures, quadruped mammals including horses, boats and sun symbols, but other figurative motifs and linear and abstract designs also occur. The Muna Island artwork can (like the Gua Pondoa art) be classified within the APT, but it is very different from Gua Pondoa in its execution and colour. Most of the designs in the Muna sites were painted in solid red ochre rather than drawn in charcoal, giving them a filled-in appearance. The Muna rock art also includes (very faded) red hand stencils, a recurrent feature of APT painted art assemblages in eastern Indonesia and East Timor, but no hand stencils were recorded in Gua Pondoa. A recurring Muna motif is horses with riders, and the human figures often appear to be holding weapons and sometimes in apparent hand-to-hand combat (e.g. Metanduno 14 in Marschall and Wäfler 2012:148-149), but representation of humans with headdresses is absent or minimal on the Muna anthropomorphs.

Mammals are abundant in the Muna sites and often identifiable as to their type, including cattle, deer, pigs and dogs. Horned ungulates similar to the Gua Pondoa 'water buffalo' are also seen in the Muna art at Lasabo 1, as are quadrupeds with back curving horns at Lasabo 5 (Marschall and Wäfler 2012:89, 97). The Muna animal paintings include hunting scenes such as the panel at Metanduno 13, which shows a human figure spearing a stag with large antlers (Marschall and Wäfler 2012:146). Horses and riders are also found in the rock art of Timor Leste at the site of Ile Kere Kere (O'Connor et al. 2018). Although both the Muna and Timor Leste art assemblages fit comfortably within Ballard's description of the art of the APT on the basis of colour, motif location and motif composition, the inclusion of definite horses and riders indicates a continuation of tradition into the Indonesian Metal Age or historic period. Horses are not endemic to Indonesia and do not occur in the prehistoric layers of archaeological sites. They are thought to have been introduced into eastern Indonesia, probably as pack animals, by Indian or Chinese traders.

Most of the boats figured in the Muna site have steeply raked prows and sterns. Most also include human rowers with the oars shown extending below the boat (e.g. Metanduno 10 in Marschall and Wäfler 2012:127). Some of the Muna boats show the sun symbols intercepting the prow of the boat, indicating a relationship between these motifs (e.g. Metanduno 8 and 20 in Marschall and Wäfler 2012:121-122, 127-128). None of these features are evident at Gua Pondoa.

A closer similarity to Gua Pondoa than the Muna artwork is the APT art from Southwest Sulawesi. For instance, Aubert et al. (2014) depict black drawings at the Leang Bulu Bettue site (Maros) that include human figures with outstretched limbs, lattice structures and series of parallel lines. Sumantri (1996) documents the variety of black paintings and drawings in the Biraeng karsts 
a short distance to the north of Maros. Similarities with Gua Pondoa include motifs of boats, one with six passengers linked arm to arm, other human figures in dynamic pose and/or arrayed in processing troupes, a quadruped mammal, a motif similar to our Figure 7.8, cross-hatching and lattice structures, squiggles and complex curvilinear designs. However, differences in detail from Gua Pondoa are again evident, such as the oval bodies of the Biraeng anthropomorphs and their lack of headdress, and the presence of fish motifs combined with a lack of sun symbols.

\section{Comparisons with other sites in eastern Indonesia and the broader Western Pacific}

The activity of creating art would not have been undertaken for the idle pursuit of 'art for art's sake', but instead as a cost-effective use of time and energy (Kosasih 1983; McDonald and Veth 2012). Also, although works of 'primitive art' are based on objects or experiences from the artists' life at the time, they incorporate cultural themes for purposes such as social solidarity and the inculcation of traditional knowledge (Kelly 2016). In the specific case of Gua Pondoa, the burial of mortuary remains towards the front of the cave, and the rear location of the artwork in a dark, moist chamber creating a sacred and magical, indeed inscrutable, impression, suggest that the execution of the art was related to the afterworld of the deceased. Thus, the drawings produced by the Gua Pondoa artists provide a visual representation of facets of their society, but probably not ones related to mundane aspects of day-to-day life.

\section{Subsistence and economy}

Evidence from the Gua Pondoa motifs informing on subsistence and economy is ambivalent. The possible depictions of a dog and an ungulate that may be a buffalo, goat or cattle would suggest a settled village lifestyle and economy. However, dogs could be kept by foragers for hunting and campsite purposes (as with Australia's dingo or 'native dog') or could be fully domestic. Similarly, the representation of ungulates with or without horns could portray either wild or domestic animals.

Indirect evidence may be more valuable for establishing an agricultural component in the subsistence economy. First, the use of caverns for mortuary purposes in Sulawesi appears to have been a specific development of low-intensity farming, as argued by Bulbeck (2010) for South Sulawesi and Bulbeck et al. (2016) for the Towuti-Routa region. Second, the dispersal of MalayoPolynesian languages across their range including Sulawesi probably involved the propagation of cultigens even if this involved a shift over time from cereal crops to tree and root crops (O'Connor 2015). There is indeed evidence for prehistoric habitation by Malayo-Polynesian speakers in Kecamatan Wiwirano, North Konawe, based on the finds of polished stone axes and earthenware pottery sherds from the 2009-1 1 Makassar Archaeology Office excavations (led by the first author) at the Gua Tengkorak site. On the other hand, Gua Pondoa is in a part of Sulawesi inhabited in ethnographic times at low population densities by hamlet-based communities (Mead 1999) and so intensive agriculture here at any time in the past appears unlikely.

As just discussed, the society that included the Gua Pondoa artists probably carved out swiddens and/or other small fields within their broader environment, which in the case of North Konawe would have been equatorial rainforest of rich ecological diversity (Whitten et al. 1987). That said, Gua Pondoa is a cultural statement of rights to occupation bequeathed by the ancestors (cf. Bulbeck et al. 2016) rather than a journalistic depiction of how society adapted to the specific 
challenges and opportunities of its environment. This perspective can accommodate themes that would be puzzling from the viewpoint of vulgar materialism, such as the depictions in a hinterland location of sizeable boats ferrying passengers.

\section{APT cultural foundations and comparison with other sites in Indonesia and the wider Western Pacific region}

The Gua Pondoa art has some features in common with APT art in other parts of eastern Indonesia and the Western Pacific, but also exhibits some distinctive features. In terms of location, the Gua Pondoa art is executed in a cave away from the sea, albeit sharing the frequently recorded feature of a locational context that would be regarded as inaccessible. The motifs are drawn in charcoal rather than painted in red pigment. Features shared with the APT are motif dominance of small anthropomorphs, boats and sun symbols. Gua Pondoa lacks hand and arm stencils, which are thought to be a prominent feature of the early APT and which are found in APT sites in Kei Kecil, Timor Leste and Papua (Röder 1956; O'Connor 2003), and the figurative motifs such as boats and anthropomorphs are so highly schematised as to be little more than suggestive of form. The Gua Pondoa humans are depicted as simple stick figures and lack the detailed features and dynamism of the small red figures seen in the Timor Leste, Kei Kecil and Kisar Island. Gua Pondoa also lacks the hand stencils found in these sites.

Boats with human figures are a common theme in APT art, as noted previously and are often interpreted as closely tied to mortuary aspects (Ballard et al. 2004). At the Niah Caves in Borneo, they are specifically interpreted as ships of the dead (Szabó et al. 2009), which would also appear relevant to Gua Pondoa with its mortuary associations. Boat-shaped coffins were widely built throughout the islands of Indonesia. Specifically, they are found across Sulawesi, not only in the Towuti-Routa region (as noted above) but also in the Enrekang and Tana Toraja hinterland of South Sulawesi (Duli 2013). Duli (2013:133) concludes that the Enrekang coffins symbolised the transport of the deceased to the spirit world where they could maintain a watch over the welfare of their descendants occupying the same social landscape.

Anthropomorphs with headdresses/head adornments constitute another common APT subject. The frequent depictions of headdresses at Gua Pondoa suggest a specific representation of ceremonies or rituals. If so, based on Sulawesi ethnography the ceremonies could have been agricultural festivities, 'shamanistic gatherings' (McCall 2017) or concerned with mortuary rites. As noted, the last of these possibilities may be of most relevance to Gua Pondoa. Although it is possible that some of these scenes were painted in the Neolithic, O'Connor et al. $(2015,2018)$ have recently noted the similarity of some of the anthropomorphs shown in the Kisar and Timor Leste panels to scenes figured on Dong Son drums. Thus, the production of rock art may be referencing images seen on other types of material culture. If Dong Son drums, the images must have been produced in the Indonesian Metal Age (the last 2000 years).

Sun symbols, a common APT motif, may have particular relevance for Sulawesi societies. As discussed by Bougas (2007), various groups in South Sulawesi traditionally associate the sun with the life force, and one group, the patuntung with their core of non-Islamic beliefs sheltered beneath an Islamic veneer, associate the rising sun with the resurrection of the spirits to return to the world of the living. The sun would certainly appear to have been a potent symbol for Gua Pondoa residents throughout time even if interpretation of exactly what it symbolised may be speculative. 
Finally, abstract curvilinear motifs also commonly feature in APT bodies of art, similar to their frequent occurrence in the 'Sa Huynh-Kalanay' decorated pottery of Neolithic to Metal Age antiquity across coastal Vietnam and insular Southeast Asia (e.g. Solheim 1967). In the specific case of Gua Pondoa, there appear to be particular similarities with the mortuary pottery decorations at the nearby site of Gua Talimbue (noted above), a point that forms a bridge to consideration of APT motifs at Gua Pondoa shared with just a small number of other sites.

Gua Pondoa also has parallels with other APT sites in Sulawesi in the representation of quadruped animals. This may partly reflect the variety of Sulawesi's forest fauna, which includes species descended from crossings by placentals from Borneo to Sulawesi at various times during the late Tertiary and Quaternary, and Java deer (apparently introduced by human agency during the Holocene), not to mention two endemic cuscus species (Whitten et al. 1987; Rozzi 2017). The variety of forest fauna may have promoted the assignment of shades of symbolic associations with the different encountered species. On the other hand, the likely identification of a dog in Figure 7.3 hints at a specific role for this domesticated human companion, whose importance for Island Southeast Asian village communities is suggested by a c. 3000 -year-old dog burial in East Timor (Gonzalez et al. 2013). Dogs also occur in the painted art of Kisar Island, to the east of Timor, in association with a variety of other motifs and scenes that suggest a Metal Age rather than a Neolithic antiquity (O'Connor et al. 2018).

As the largest and the most ecologically diverse island in Wallacea, located close to the sub-continental island of Borneo and creating a bridge between the tropical regimes of the Philippines to the north and Nusatenggara to the south, Sulawesi occupies a strategic position as a crossroad for cultural influences reaching across ISEA. Wherever the APT might have started - and the location of its single or multiple origins is far from ascertained (O'Connor 2015) — Sulawesi likely had a central role in its transmission, no doubt enriching the tradition rather than standing as a passive intermediary.

\section{Conclusion}

The Gua Pondoa drawings present an iconography quite distinct from that of the earliest tradition of parietal art in Sulawesi, which was based on hand stencils and naturalistic depictions of ungulates, and which has a Late Pleistocene time depth. Hand stencils are absent from Gua Pondoa. And while there are some quadruped depictions at Gua Pondoa, their naturalistic status is debatable, added to which is the point that the earliest parietal art in Sulawesi's southeast arm appears to have been limited to hand stencils. Instead, the Gua Pondoa drawings can be assigned to the so-called 'Austronesian Painting Tradition' with its presumed maximum time depth of several thousand years in ISEA. Having said this, the Gua Pondoa art does not share all the characteristics typically assigned to APT rock art elsewhere in eastern Indonesia or in East Timor. Gua Pondoa rock art is produced in black pigment rather than red and is highly schematised. The anthropomorphs are shown with headdress but are static in pose rather than dynamic. This may indicate regional variation in the APT in Sulawesi such as is found with the black art in Vanuatu, or it may be that Gua Pondoa dates more recently in time than the red painted assemblages. The presence of scenes with horses and riders in the red painted art of Muna Island allows for either possibility.

Although the research program at Gua Pondoa has not been completed, for the time being it can be proposed that the cave was probably not a habitation site, but instead used for rituals, notably burials. The mortuary associations of the artwork strongly contextualise its limitations for attempts to reconstruct the lifeways of the society that produced the Gua Pondoa art. Instead, it should be interpreted as symbolic of the perceptions the people had of the mortuary belief systems. This point is well represented by the depictions of boats carrying passengers, which are 
unlikely to reflect the material culture and transport means of the hinterland habitants living in the environs of Gua Pondoa, but instead the passage of the souls of the deceased, as noted widely amongst the Malayo-Polynesian speakers of Sulawesi and other islands.

The Gua Pondoa iconography may have limited applicability as a direct source of evidence on the lifeways of its associated society, the establishment of a cave for community mortuary practices, combined with the observation of a settlement pattern of low-density hamlets in ethnographic times, suggests that Gua Pondoa may have been connected to a subsistence system based on garden plots carved out of the local equatorial forests. In summary, the Gua Pondoa charcoaldrawn art adds to our knowledge of the diversity of the pigment art corpus in Sulawesi, and contributes to a perspective in which localised expressions of the APT shared common roots at some level but were also tuned to divergent trajectories and a diversity of local world views.

\section{Author biographies}

Budianto Hakim Makassar Archaeology Office, Makassar, South Sulawesi, Indonesia

Sue O'Connor Department of Archaeology and Natural History, School of Culture, History and Language, College of Asia and the Pacific, The Australian National University, Canberra, Australia; and ARC Centre of Excellence for Australian Biodiversity and Heritage, The Australian National University, Canberra, Australia

David Bulbeck Department of Archaeology and Natural History, School of Culture, History and Language, College of Asia and the Pacific, The Australian National University, Canberra, Australia

\section{References}

Aubert, M., A. Brumm, M. Ramli, T. Sutikna, E.W. Saptomo, B. Hakim, M.J. Morwood, G.D. van den Bergh, L. Kinsley and A. Dosseto. 2014. Pleistocene cave art from Sulawesi, Indonesia. Nature 514(7521):223-227. doi.org/10.1038/nature13422 (accessed 5 June 2018).

Ballard, C. 1988. Dudumahan: a rock art site on Kai Kecil, SE Moluccas. Bulletin of The Indo-Pacific Prehistory Association 8:139-161. doi.org/10.7152/bippa.v8i0.11274 (accessed 5 June 2018).

Ballard, C. 1992. Painted rock art sites in western Melanesia: Locational evidence for an 'Austronesian'tradition. In J. McDonald and I. Haskovec (eds), State of the Art: Regional Rock Art Studies in Australia and Melanesia, pp. 94-106. Occasional AURA Publication 6. Melbourne: Australian Rock Art Research Association.

Ballard, C., R. Bradley, L.N. Myhre and M. Wilson. 2004. The ship as symbol in the prehistory of Scandinavia and Southeast Asia. World Archaeology 35(3):385-403. doi.org/10.1080/0043824042000185784 (accessed 5 June 2018).

Bougas, W.A. 2007. Gold looted and excavated from late (1300 AD-1600 AD) pre-Islamic Makasar graves. Archipel 73(1):111-166. doi.org/10.3406/arch.2007.3877 (accessed 5 June 2018).

BPK RI (Badan Pemeriksa Keuangan Republik Indonesia). 2009. Profil Kabupaten Konawe Utara. kendari. bpk.go.id/?page_id=392 (accessed 5 February 2017).

Brumm, A., M.C. Langley, M.W. Moore, B. Hakim, M. Ramli, I. Sumantri, B. Burhan, Andi M. Saiful, L. Siagian, Suryatmane, R. Sardi, A. Jusdi, Abdullahj, A. Pampan Mubarakj, Haslianae, Hasriantie, A. A. Oktaviana, S. Adhityatamak, G.D. van den Bergh, M. Aubert, J. Zhao, J. Huntley, B. Lil, R.G. Roberts, E. Wahyu Saptomok, Y. Perstond and R. Grün. 2017. Early human symbolic behavior in the Late Pleistocene of Wallacea. PNAS 114(16):4105-4110. www.pnas.org/content/114/16/4105 (accessed 5 June 2018).

\section{terira australis 48}


Bulbeck, D. 2010. Uneven development in Southwest Sulawesi, Indonesia during the Early Metal Phase. In B. Bellina, E.A. Bacus, T.O. Pryce and J.W. Christie (eds), 50 Years of Archaeology in Southeast Asia: Essays in Honour of Ian Glover, pp. 153-169. Bangkok: River Books.

Bulbeck, D. 2018. Holocene site occupancy in Sulawesi. In S. O’Connor, D. Bulbeck and J. Meyer (eds), The Archaeology of Sulawesi: Current Research on the Pleistocene to the Historic Period, pp. 93-116. Canberra: ANU Press.

Bulbeck, D., F.A. Aziz, S. O’Connor, A. Calo, J.N. Fenner, B. Marwick, J. Feathers, R. Wood and D. Prastiningtyas. 2016. Mortuary caves and the dammar trade in the Towuti-Routa region, Sulawesi, in an Island Southeast Asian context. Asian Perspectives 55(2):148-183. doi.org/10.1353/asi.2016.0017 (accessed 5 June 2018).

Duli, A. 2013. The mandu coffin: A boat symbol of ancestral spirits among the Enrekang people of South Sulawesi. Review of Indonesian and Malaysian Affairs 47(1):115-138.

Gonzalez, A., G. Clark, S. O'Connor and L. Matisoo-Smith. 2013. A 3000 year old dog burial in Timor-Leste. Australian Archaeology 76(1):13-20. doi.org/10.1080/03122417.2013.11681961 (accessed 5 June 2018).

Hakim, B. 2006. Interpretasi lukisan hasil survei di Gua Pominsa dan Sugi Patani, Kabupaten Raha, Sulawesi Tenggara: Lukisan masa prasejarah atau bukan? Walennae 9(2):51-61.

Intan, M.S.F. 2005. Geologi situs-situs gua (Pinda, Paminsa, Lansifora 2, Lakuba) Kabupaten Muna, Provinsi Suawesi Tenggara. In D.W. Utomo, Hasanuddin, B. Hakim and A.F. Umar (eds), Menguak Tabir Kehidupan Masa lalu dan kini, pp. 85-102. Makassar: Balai Arkeologi Makassar/Hasanuddin University Press.

Kelly, L. 2016. The Memory Code. New York: Pegasus Books.

Kosasih, E.E. 1983. Tradisi Berburu pada Lukisan Gua di Pulau Muna (Sulawesi Tenggara). Cisarua: REHPA I.

Lape, P.V., S. O'Connor and N. Burningham. 2007. Rock art: A potential source of information about past maritime technology in the south-east Asia-Pacific region. International Journal of Nautical Archaeology 36(2):238-253. doi.org/10.1111/j.1095-9270.2006.00135.x (accessed 5 June 2018).

Marschall, W. and M. Wäfler. 2012. Fels-male reien Indonesiens. Band 1: Pulau Muna. Borsdorf: Edition Winterwork.

McCall, G.S. 2017. Add shamanism and stir? A critical review of the shamanism model of forager rock art production. Journal of Anthropological Archaeology 26:224-233. doi.org/10.1016/j.jaa.2006.09.001 (accessed 5 June 2018).

McDonald, J. and P. Veth (eds). 2012. A Companion to Rock Art. Hoboken, NJ: Blackwell.

Mead, D.E. 1999. The Bungku-Tolaki Languages of South-Eastern Sulawesi, Indonesia. Pacific Linguistics Series D, Volume 91. Canberra: The Australian National University.

Nurhasan, I., V. Isnaniawardhani and N. Sulaksana. 2013. Penentuan kawasan pertambangan berbasis sektor komoditas unggulan sumberdaya nikel Kabupaten Konawe dan Konawe Utara Provinsi Sulawesi Tenggara. Buletin Sumber Daya Geologi 8(2):41-53.

O'Connor, S. 2003. Nine new painted rock art sites from East Timor in the context of the Western Pacific region. Asian Perspectives 42(1):96-128. doi.org/10.1353/asi.2003.0028 (accessed 5 June 2018).

O'Connor, S. 2015. Rethinking the Neolithic in island Southeast Asia, with particular reference to the archaeology of Timor-Leste and Sulawesi. Archipel 90:15-48. doi.org/10.4000/archipel.362 (accessed 5 June 2018). 
O'Connor, S., J. Louys, S. Kealy and Mahirta. 2015. First record of painted rock art in Kupang, West Timor, Indonesia and the origins and distribution of the Austronesian Painting Tradition. Rock Art Research 32(2):193-201.

O’Connor, S., Mahirta, D. Tanudirjo, M. Ririmasse, H. Mohammad, S. Kealy, S. Hawkins and Alifah. 2018. Ideology, ritual performance and its manifestations in the rock art of Timor-Leste and Kisar Island, Island South East Asia. Cambridge Archaeology Journal 28(2):225-241. doi.org/10.1017/ S095977431700816 (accessed 5 June 2018).

Oktaviana, A.A. 2018. Hand stencils and boats in the painted rock art of the karst region of Muna Island, Southeast Sulawesi. In S. O'Connor, D. Bulbeck and J. Meyer (eds), The Archaeology of Sulawesi: Current Research on the Pleistocene to the Historic Period, pp. 61-78. Canberra: ANU Press.

Oktaviana, A.A., D. Bulbeck, S. O’Connor, B. Hakim, Suryatman, U.P. Wibowo, E. St Pierre and Fakhri. 2016. Hand stencils with and without narrowed fingers at two new rock art sites in Sulawesi, Indonesia. Rock Art Research 33(1):32-48.

Röder, J. 1938. Felsbildforschung auf West-Neuguinea. Paideuma 1(2):75-88.

Röder, J. 1956. The rock paintings of the MacCluer Bay. Antiquity and Survival 1:387-400.

Rozzi, R. 2017. A new extinct dwarfed buffalo from Sulawesi and the evolution of the subgenus Anoa: An interdisciplinary perspective. Quaternary Science Reviews 157:188-205. doi.org/10.1016/j.quascirev. 2016.12.011 (accessed 5 June 2018).

Simons, A.C. 1997. The Whole Hog. The Indigenous Response to the Introduction of Farming to South Sulawesi: A Faunal Analysis. Bachelor of Arts (Hons) dissertation. Perth: University of Western Australia Centre for Archaeology.

Simons, A.G. and D. Bulbeck. 2004. Late Quaternary faunal successions in South Sulawesi, Indonesia. In S.G. Keates and J.M. Pasveer (eds), Quaternary Research in Indonesia, pp. 167-189. Modern Quaternary Research in Southeast Asia, Volume 18. Leiden: A.A. Balkema.

Solheim, W.G. II. 1967. The Sa-huynh-Kalanay pottery tradition: Past and future research. In M.D. Zemora (ed.), Studies in Philippine Anthropology, pp. 151-174. Quezon City: Alemar-Phoenix Publishing House.

Sumantri, I. 1996. Pola Pemukiman Gua-Gua Prasejarah di Biraeng Pangkep, Sulaswesi Selatan. Unpublished MA thesis, Program Studi Arkeologi, University of Indonesia, Jakarta.

Szabó, K., P.J. Piper and G.W. Barker. 2009. Sailing between worlds: The symbolism of death in northwest Borneo. In G. Clark, F. Leach and S. O'Connor (eds), Islands of Enquiry: Colonisation, Seafaring and the Archaeology of Maritime Landscapes, pp. 149-170. Terra Australis 29. Canberra: ANU E Press.

Taçon, P., M. Ramli, B. Hakim, A. Brumm and M. Aubert. 2018. The contemporary importance and future of Sulawesi's rock art. In S. O'Connor, D. Bulbeck and J. Meyer (eds), The Archaeology of Sulawesi: Current Research on the Pleistocene to the Historic Period, pp. 31-42. Canberra: ANU Press.

Whitten, T., M. Mustafa and G.S. Henderson. 1987. The Ecology of Sulawesi. Yogyakarta: Gadjah Mada University Press.

Wilson, M. 2002. Picturing Pacific Prehistory: The Rock Art of Vanuatu in a Western Pacific Context. Unpublished PhD thesis, Department of Archaeology and Natural History, The Australian National University, Canberra. 
This text is taken from The Archaeology of Sulawesi: Current Research on the Pleistocene to the Historic Period, edited by Sue O'Connor, David Bulbeck and Juliet Meyer, published 2018 by ANU Press, The Australian National University, Canberra, Australia.

doi.org/10.22459/TA48.11.2018.07 